\title{
Çok Katlı Yapılarda Kritik Deprem Doğrultusunun Belirlenmesi
}

\section{Determination of earthquake critical angle direction in multistory structures}

\author{
Burcu Ayar 1(D), Ahmet Anıl Dindar ${ }^{*}$ (I) \\ ${ }^{1}$ Gebze Teknik Üniversitesi Mühendislik Fakültesi, Kocaeli, TÜRKIYE \\ Sorumlu Yazar / Corresponding Author*: adindar@gtu.edu.tr
}

Geliş Tarihi / Received: 26.05 .2020

Araştırma Makalesi/Research Article

Kabul Tarihi / Accepted: 19.01.2021 DOI:10.21205/deufmd.2021236812

Atıf sekli/How to cite: AYAR B., DINDAR A.A.(2021). Çok Katlı Yapılarda Kritik Deprem Doğrultusunun Belirlenmesi. DEÜ FMD 23(68), 489500 .

Öz

Geçtiğimiz yüzyll içinde bütün dünyada, deprem yönetmelikleri uygulanmaya bașlamıştır. Deprem etkisini yapıya en basit anlamda etkimesini temsil eden "Eşdeğer Statik Yükleme ile Analiz Yöntemi" geçerliliğini halen korumaktadır. Bununla birlikte teknolojideki gelișmelerin katkısıyla, deprem kayıtları yapı analizlerinde kullanılmaya başlanmıştır. Deprem kayıtları kullanılarak "Zaman Tanım Alanında Analiz" uygulamaları ile deprem kuvvetlerinin yapıya etki ettirilmesi konusunda var olan belirsizliklerin bir kısmı ortadan kaldırılmıştır. Deprem yönetmeliklerinin tümünde, yapıların planda simetrik olması ve düzenli taşıyıcı sistem modeline sahip olmasının gerekliliği vurgulanmıştır. Yapılarda, sistem geometrisi ve taşıyıcı sistem düzensizlikleri sebebi ile burulma kuvvetleri oluşmaktadır. Zira, kütle merkezi ile rijitlik merkezinin çakışmaması durumu burulma kuvvetlerinin kritik etkisinin artmasına sebep olmaktadır. Yönetmeliklerde düzensizlik durumları sınır değerlerin üzerinde olan yapılar için güvenliği sağlamak üzere ek önlemler alınmaktadır. Gerçek hayatta, depremin yapıya hangi doğrultuda etkiyeceğini bilmek imkansızdır. Bu yüzden deprem yönetmelikleri çeşitli birleştirme yöntemleri önererek deprem kuvvetlerinin etkisini hesaplamaya yönelik formüller vermiștir Bu çalışma kapsamında depremin belirsizliklerinden biri olan deprem kayıt çiftlerinin yapıya asal eksenleri dışında gelmesi durumu ve yapıların planda düzenli veya düzensiz olması durumundaki etkileşimi çalışılmıştır. Bu çalışmada, yapıların burulma düzensizliği ve deprem kuvvetlerinin farklı doğrultularda etkimesi dikkate alınarak, farklı yapı tiplerine bağlı olarak kritik açı etki doğrultusu belirlenmiştir. Önerilen kritik açı etki yaklaşımı, yönetmeliklerde verilen birleștirme yöntemleri ile karşılaștırılmış ve sayısal bir örnek üzerinde uygulaması yapılmıştır.

Anahtar Kelimeler: Kritik açı etkisi, deprem yüklerinin çok yönlü etkimesi, elastik tepki, düzenli yapılar, düzensiz yapılar

\begin{abstract}
During the last century, seismic codes have been implemented in all over the world. Equivalent seismic loading has been a prevalent method in representing earthquake forces. In addition, as the development of technology real earthquake records are used in building analysis. By using earthquake records, time domain analysis was applied and some of the uncertainties in determining the earthquake forces were eliminated. The modern seismic codes require that the buildings should be symmetrical in the plan and have a regular structural system. Torsional response may occur in
\end{abstract}


DEÜ FMD 23(68), 489-500, 2021

structures due to system geometry and irregular structural system. In seismic codes, several actions are taken as counter measure to provide the safety of the buildings having torsion above the given limits. The reality is that the prediction of the earthquake forces effect direction is not possible. Thus, the seismic codes recommend the combination formulas for the earthquake forces. In this study, structural irregularity and varying earthquake forces have been taken account in the computation of the critical angle. The recommended critical angle approach has been compared with the combination methodology and demonstrated for given numerical example.

Keywords: Critical angle effect, multi-dimensional impact of earthquake loads, elastic response, regular structures, irregular structures

\section{Giriş}

Ülkemiz tamamına yakını deprem kuşağında bulunması sebebiyle tasarlanan hemen hemen tüm binaların ekonomik ömürleri boyunca bir veya daha fazla deprem etkisine maruz kalmaktadır. Yapıya gelmesi muhtemel yüklerin doğru hesaplanması ve bu yüklerin yapılara doğru șekilde taşıttırılması çok büyük önem arz etmektedir. Yaşanan büyük depremlerde elde edilen sonuçlar göstermiştir ki, birçok binanın yıkılma sebebi arasında yanlış tasarım, dikkate alınmayan yapı düzensizlikleri, elverişsiz zemin koşuları gibi temel mühendislik kavramları yer almaktadır.

Sayısal hesaplamalarda, üç boyutlu modeller üzerinden deprem kuvvetlerinin yatay ve gerekirse düşey bileșenin kullanılması söz konusudur. Yönetmelikler, yürütülecek analizlerde gerçek deprem kayıtlarının kullanılmasını teșvik etmekle beraber kaydın yapıya hangi doğrultuda uygulanacağı hakkında herhangi bir ifade bulundurmamaktadır [1].

Deprem kuvvetlerinin yapılarda sebep olduğu deprem yüklerinin, yapıların planda görülen asal eksenleri dışında farklı bir doğrultudan etkimesi durumunda (doğrultu etkisini), yapilarda oluşacak kritik davranış büyüklüklerinin tasarım așamasında kontrol edilebilmesi amacı ile çeșitli birleştirme kuralları önerilmiştir. Bu birleştirme kuralları genel olarak;

- $\quad \% 30$ Birleştirme Kuralı [2],

- \%40 Birleștirme Kuralı [3],

- SRSS (Karelerin Toplamının Karekökü) Birleştirme Kuralı [4],

- CQC3 Birleștirme Kuralı [5],

- Lopez ve Torres (1997) tarafından önerilen Birleştirme Kuralı [6],

- Etkileșimli Süperpozisyon Kuralı [7],

Yukarıda sözü geçen birleștirme kurallarında, en elverișsiz durumu veren kritik etki doğrultu açısı ile ilgili bazı bağıntılar önerilmiștir. Deprem kuvvetlerinin kritik etkisi literatürde, birçok alanda farklı araştırmalara konu olmuştur.

Sebastiani ve diğerleri [8] tarafından yapılan bir araştırmada özellikle yakın fay etkisine maruz kalan yapılar için kritik etki değerlendirilmesi çalışması yapılmış ve iki farklı vaka çalışması değerlendirilerek çözüm için örnek bir prosedür elde edilmeye çalışılmıştır. $0^{\circ}-180^{\circ}$ arasında $22.5^{\circ}$ 'lik açı değişimleri ile analizler tamamlamıştır. Ayrıca iki serbestlik derecesine sahip bir model prosedür kapsamında dinamik analizleri uygulamak için oluşturulmuş olup doğrusal olan ve olmayan analizler yapılmıștır. Çalışma sonucunda kritik etki açısının sadece yapı geometrisi ile değil yapıya gelen deprem kuvvetlerinin karakteristiği ile ilgili olduğunu savunmuştur. Ayrıca kritik etki doğrultusu araştırılırken olup doğrusal olan ve olmayan analizler sonucu elde edilen kritik açı değerlerinin oldukça yakın değerler olduğu gözlemlenmiștir.

Maglio ve diğerleri [9] çalışmasında kritik etki açısının sismik performans üzerindeki değişimini gözlemleyebilmek için planda düzensiz betonarme yapılar üzerinde doğrusal olmayan statik ve dinamik analizler yapmıştır. Deprem kuvvetlerini $0^{\circ}-330^{\circ}$ aralığında $30^{\circ}$ lik adımlarla döndürerek analizler yapmış ve sonuçları mühendislik talep parametreleri (plastik mafsal dönmeleri ve çatı yer değiştirmeleri) açısından değerlendirmiştir. Bu parametrelerde bazı açı değerlerinde \%37'ye varan farklar ile karşılaşmıştır.

Kostinakis ve diğerleri [10] konu ile ilgili çalışmalar yapmak için sekiz adet farklı geometriye sahip yapı ile deprem kayıtlarını farklı doğrultularda çevirerek analizler yapmış ve yapıların sismik hasar seviyelerinin dıș merkezlik ile faya olan uzaklığı ile bir bağlantısı olduğunu söylemiştir. 
Giannopoulos ve diğerleri [11] 2018 yılında yapılan çalıșmada deprem kuvvet çiftlerinin FNFP doğrultularına çevrilmesi ve orijinal hali ile kaydedilen deprem kayıtlarının farklı doğrultularda uygulanması durumunda, belirlenen mühendislik parametrelerinde oluşan değișimleri araștırmıștır. Analizler yapılırken tek serbestlik dereceli ve çok serbestlik dereceli sistemler kullanılmıştır. Az sayıda kayıt ve çok doğrultulu analizler ile çok sayıda kayıt ve herhangi bir etkime açısı ile hesap yapılması durumları karşılaştırılmıştır.

Altunışık ve Kalkan [12], 2017 yaptıkları çalıșmada deprem kayıtları $0^{\circ}-90^{\circ}$ aralığında farklı doğrultularda yapılara uygulamış ve belirlenen mühendislik talep parametrelerinin karşılaştırılmaları yapılmıștır. Çalışmada beș katlı çerçeve bir yapı üzerinden değerlendirmeler yapılmıstır. İncelenen mühendislik talep parametreleri ile ilgili bazı açılarda \%37-\%54 arası daha yüksek sonuç parametreleri gözlemlenmiştir.

2015 yılında Kalkan ve Reyes [13] çok katlı simetrik ve simetrik olmayan yapılara, yakın saha kaynaklı deprem kuvvetleri hesaplanmış ve deprem kuvvetlerinin farklı açlarda etkimesi sonucu elde edilen mühendislik parametrelerini değerlendirmiștir. Gene Kalkan ve Reyes'in yaptığı sıralı çalıșmalarda [14,15] yapılara deprem kuvvet çiftlerinin fay paralel ve fay normal doğrultularına çevrilmesi ve bu doğrultularda uygulanan kayıtlarda zaman tanım alanında analizler yapılması sonucu elde edilen parametreleri karşılaştırmıștır. Fay paralel fay normal doğrultularında çevrilmeden elde edilen kayıtların artı ve eksi yönlerini ayrıca incelemiştir. Sonuç olarak deprem kayıtlarının FN-FP doğrultularına çevrilmesi ve en olumsuz tepki kuvvetlerinin ortaya çıktığı kritik açının tasarıma esas olarak kullanılmasını önermiştir.

Hasgül [16] tarafından 2011 yılında hazırlanan doktora çalışmasında deprem yüklerinin doğrultu etkisi nedeniyle betonarme binaların kiriş ve kolon plastik kesitlerinde (plastik mafsallarında) oluşacak en elverișsiz plastik şekildeğiștirme talepleri ile bunları veren kritik deprem doğrultularının doğrusal olmayan teori çerçevesinde araștırılması amaçlanmıștır. Bu çalışmada kritik etki açısı kavramının önemi elde edilen analiz sonucu verileri ile desteklenmiștir.

Bugüne kadar yapılan çalışmalar elverişsiz bir deprem doğrultusu olduğu gerçeğini vurgulamaktadır. Deprem kuvvetlerinin, yapı asal eksenleri doğrultusunda ve bunun dıșındaki doğrultularda uygulanması ile elde edilen etkilerin farklı olabileceğini kanıtlamıștır. En elverişsiz sismik etkinin oluşacağı kritik deprem doğrultusu, seçilen deprem kayıtlarına bağlı olduğu kadar yapının geometrik özelliklerine de bağlıdır [17].

Çok yakın zamanda yapılan kapsamlı bir çalışmada [18], ardışık kuvvetli yer hareketlerinin tek serbestlik dereceli bir yapıya farklı açılarla etkimesi durumu incelenmiştir. Sözkonusu çalışma, önceki çalışmalardan farklı olarak kritik etki açısının belirlenmesini yapı periyoduna bağlı olarak irdelemiștir. Çalıșma sonunda, sabit-dayanım süneklik için doğrusal olmayan spektralar önerilmekle beraber, ana ve artçı şok kayıtlarının değişik etki açılarının çıkartılmasının gerekliliği vurgulanmıştır.

$\mathrm{Bu}$ çalıșma kapsamında planda düzenli ve düzensiz binalardan olușan yapı seti oluşturulmuş, sahaya özel hazırlamış Türk Deprem Yönetmeliği'ne uyumlu, yönelim etkisi ortadan kaldırılmış deprem kayıtları ile zaman tanım alanında doğrusal hesaplamalar (ZTADH) yapılmıștır. Deprem kayıt çiftleri tüm yapılarda $15^{\circ}$ lik adımlarla hesaplamaya katılmıştır. Elde edilen sonuçlar istatistiki olarak değerlendirilmiş ve yapı seti sınıflandırılmasına göre kritik açı değerleri önerilmiştir.

\section{Yöntem}

Bu çalıșmada geometrik ve yapısal açıdan farklı özelliklere sahip dört farklı sınıfta toplanmış yapıların, deprem dinamik kuvvetlerinin farklı açılar altında etkimesi sonucu ortaya çıkan sonuçları çalıșılmıștır. Hesaplamalarda üç boyutlu modellemeler kurulmuș ve doğrusal elastik hesap yöntemleri kullanılarak dinamik analizler yapılmıştır. Bu çalışma içerisinde yapı eleman tasarımı ve dolayısıyla eleman kapasitesine yönelik olarak donatı hesaplamaları yapılmamıștır. Bunun yerine, yapı tasarımında kullanılmasına yönelik bir analiz yöntemi önerilmeye çalışılmıştır.

Deprem kuvvetlerinin etkilerinin birleșim kuralı yönetmeliğimizde "Ortak Etki Formülleri” olarak verilen $\% 30$ birleștirme kuralı yöntemi uygulanmış ve sonuçları zaman tanım alanında yapılan analiz sonuçları ile karșılaștırılmıștır [17]. Az ve orta katlı olarak seçilen bu yapıların düzenli veya düzensiz geometriye sahip olması durumunda ve perde kullanımına bağlı olarak 
DEÜ FMD 23(68), 489-500, 2021

deprem kuvvet çiftlerinin farklı açlarda etkimesi sonucu olușacak etkisi analiz sonuçları ile belirli parametreler aracılığı ile karşılaştırılmıştır.

Yapıların hasar durumları incelendiğinde burulma kuvvetlerinin önemli rol oynadığını gözlemlenmektedir. Yönetmelikler, yapılara etkiyen dinamik deprem kuvvetlerinin birbirine dik ve yapının asal eksenleri boyunca etkidiğini kabul etmiştir. Asal eksenleri deprem doğrultularına dik olmayan elemanlar içeren yapılar için ise yönetmeliklerde verilen "Ortak Etki Formülleri”nin kullanılmasını önermiştir [17]. Calıșmada deprem kuvvetlerinin etkilerinin, betonarme binaların plandaki asal eksenlerine ilave olarak farklı doğrultularda etkimesi durumunda, belirlenen mühendislik parametreleri açısından, en elverișsiz değerleri veren kritik etki doğrultusunun hesaplanabilmesi için, farklı plan ve en kesite sahip yapılara elastik doğrusal analizler uygulanmıştır.
Bu çalıșmada yönetmelikte verilen "Ortak Etki Formülleri" ile birlikte gerçek kayıtlar kullanılarak yönelim etkisi ortadan kaldırılmış ve Deprem Bölgelerinde Yapılacak Yapılar Hakkında Yönetmelik (DBYBYH-2007) [17] içerisinde verilen elastik tepki spektrumuna uygun olarak ölçeklendirilmiş deprem kayıtları kullanılmıştır. Simetrik ve elemanlarının asal eksenleri deprem doğrultularına paralel olan yapılar ile simetrik olmayan ve asal eksenleri deprem doğrultularına paralel olmayan yapılara, çalıșma kapsamında belirlenen deprem kayıtları $0^{\circ}$ den başlayıp $15^{\circ}$ derecelik adımlarla $360^{\circ}$ dereceye kadar $\left(0^{\circ}, 15^{\circ}, 30^{\circ} \ldots 360^{\circ}\right)$ uygulanmıs ve sonuçlar yönetmelikte verilen "Ortak Etki Formülleri” ile karşılaştırılmıştır. Yapıların simetri durumu, burulma katsayıları gibi geometrik özellikleri ile maksimum tepkilerin görüldüğü kritik etki doğrultusu kavramı arasında bir ilişki kurulmaya çalıșılmıştır.

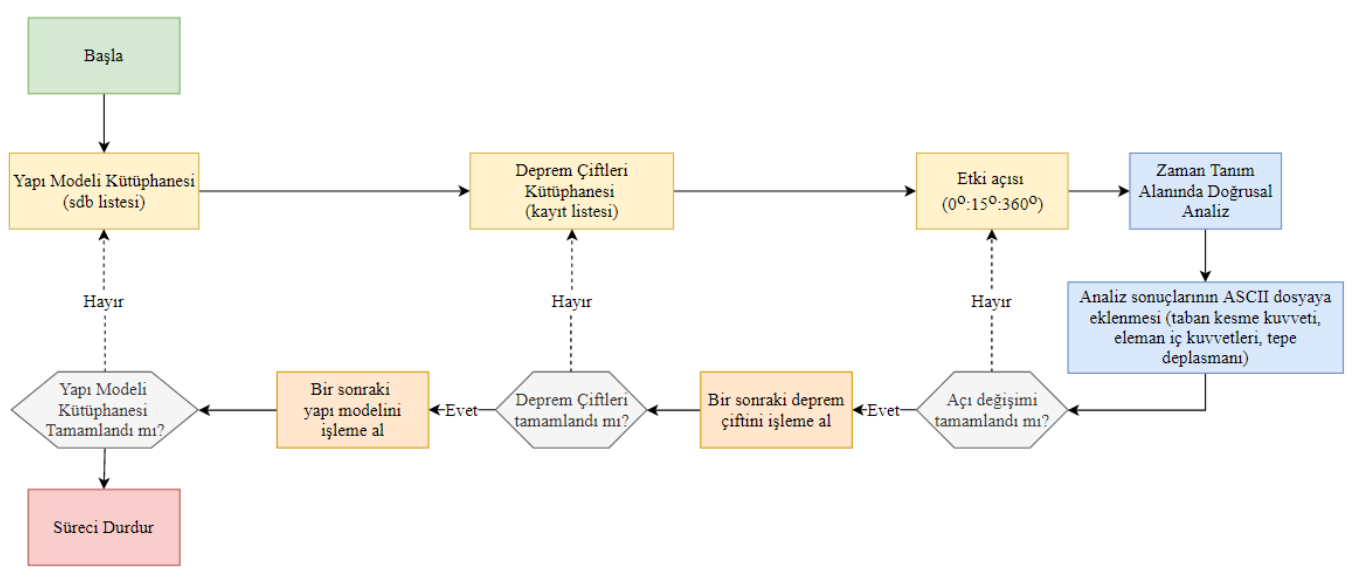

Şekil 1. Çalışmada izlenen hesap yöntemi

Calıșmada yapısal analizler için CSI SAP2000 (v.16) [19] programı kullanılmıștır. Toplamda 185 adet örnek bina, yedi farklı deprem kaydı altında ve deprem kuvvetlerinin doğrultuları değiştirilerek incelenmiştir. Böylece zaman tanım alanında yapılan toplam analiz sayısı 32,375 olmuștur. Analizlerin manuel yapılması ve analiz sonucu ortaya çlkan veri grubunun incelenmesi çok zor olacağından Python dilinde geliştirilen "SAMA" isimli program, SAP2000 analiz programı ile birlikte çalıștırılmıs (Şekil1) ve analizlerin ardışık ve kullanıcı müdahalesi olmadan sürdürülmesi sağlanmıștır [20]. SAMA'nın kullanılması ile birlikte, her bina sınıfı için ortalama 8,000 analiz yaklașık 15 saatte otomatik olarak çözülmüş ve ilgili mühendislik parametrelerine ait sonuçlar elde edilmiştir. Ardında, seçilen parametreler üzerinde istatiksel çalıșma yapılmıștır.

\section{3. Önerilen hesap adımları}

Çalışmada kullanılan yapı seti, dört farklı yapı sinıfından olușmaktadır. Modellemeler ve analizler uygulanırken kat ağırlıkları kullanılan program tarafindan hesaplatılmıș ayrıca hareketli yük olarak $2.5 \mathrm{kN} / \mathrm{m}^{2}$, döşeme yükü olarak $2 \mathrm{kN} / \mathrm{m}^{2}$ tanımlanmıştır.Yapı setinde kullanılan kolon boyutları $30 \mathrm{~cm} \times 30 \mathrm{~cm}$ ve 
$40 \mathrm{~cm} \times 40 \mathrm{~cm}$ olarak değișmekte olup, kiriş boyutları $50 \mathrm{~cm} \times 25 \mathrm{~cm}$, döşeme kalınlığ $13 \mathrm{~cm}$, perde duvar boyutları $20 \mathrm{~cm} \times(100-150) \mathrm{cm}$ olarak belirlenmiștir. Beton sınıfı C20/25, donatı S420 olarak kullanılmıștır. Yapılar $X$ ve $Y$ doğrultularında iki akstan başlayıp beş aksa kadar değișen aks adetleri oluşmaktadır ve bu aks aralıkları $5 \mathrm{~m}$ olarak belirlenmiştir. Kat yükseklikleri ise birbirine komşu iki kat arasında $3 \mathrm{~m}$ olarak seçilmiştir. Yapıların analizler sonucu değerlendirmelerinin yapılabilmesi için, belirli mühendislik parametrelerinin karşılaștırılması yapılmıștır. Mühendislik sonuç parametreleri
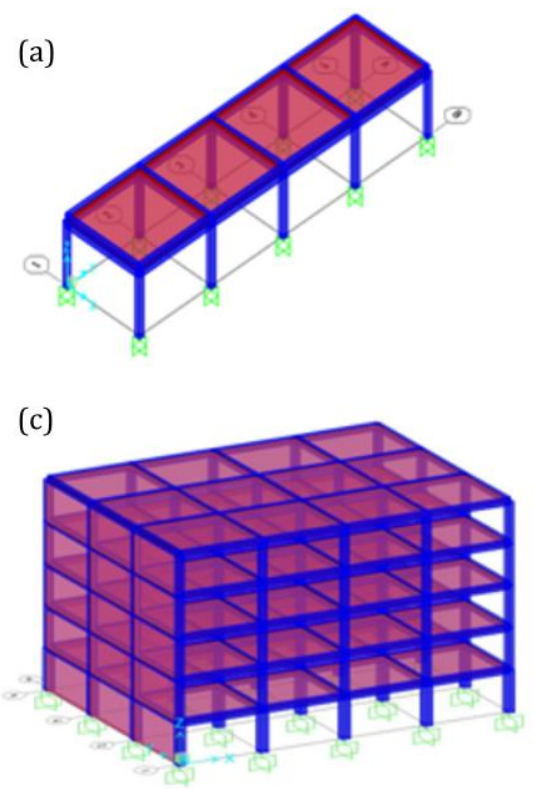

olarak ele alınıp karşılaștırmaları yapılan değerlerlendirme parametreleri için; tepe yerdeğiștirme değerleri bina yüksekliği ile, taban kesme kuvvetleri bina ağırlı̆̆ı ile oranlanmıștır. Böylece bütün yapılar için incelenmesi daha kolay ve karşılaştırmalar yapılırken daha anlamlı sonuç aralıkları elde edilmiștir. Çalıșılan yapı gruplarının sınıflandırılırken kritik etki doğrultusunun araştırılabilmesi için, analiz sonuçları plan oranları, birinci ve ikinci titreșim periyotlarının oranı ve burulma katsayıları gibi parametrelere dikkate alınmıștır.

(b)

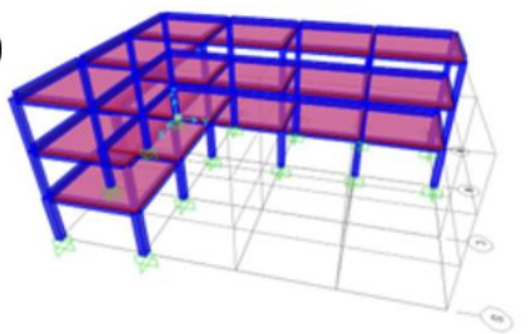

(d)

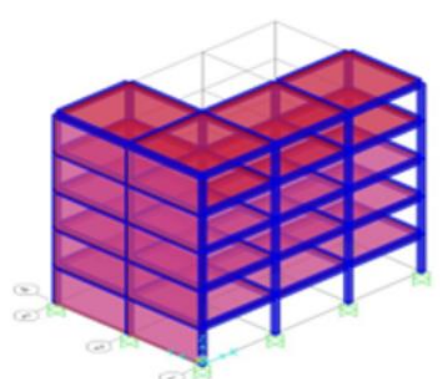

Şekil 2. Yapı sistemlerinin sınıflandırılması örnekleri (a) Düzenli-Burulmasız, (b) DüzensizBurulması, (c) Düzenli-Burulmalı ve (d) Düzensiz-Burulmalı

Belirtilen sinıflandırmada geometrik özellikler (planda düzenli veya düzensiz), ve burulma etkisinin varlığına (perdesiz ve perdeli) göre dört grup belirlenmiştir, sırasıyla; (a) DüzenliBurulmasız:, (b) Düzensiz-Burulmasız, (c) Düzenli-Burulmalı ve (d) Düzensiz-Burulmalı olarak adlandırılmıştır (Şekil2). Yapılarda, 2 ila 5 arasında değișen aks sayısı ve 1-3-5 adet kat düzlemi olduğu düşünülmüștür. Dolayısıyla düzenli ve düzensiz yapılarda, sırasıyla, 16 ve 15 'er adet, burulma hali ve kat saylarının da dikkate alınması ile toplamda 185 yapı modeli ile işlemler sürdürülmüștür. Düzenli yapılar için tüm akslarda ve aralıklarda taşıyıcı sistem yer aldığı düșünülürken, düzensiz yapılarda eleman azaltılmasına gidilmiștir. Düzensiz-Burulmasız yapılarda hesaplanan düzensizlik oranları, DBYBYH-2007'de tanımlanan limit değer olan 1.2'yi aşmadığından, burulma yaratabilmek için bir diş kenar aks boyunca düșeyde sürekliliği olan perdeler eklenmiştir.

\subsection{Deprem yer hareketleri}

Zaman tanım alanında analizler yapılırken, İstanbul'da yer alan, 1. derece deprem bölgesi ve zemin sınıfi Z2 olan bir konum için DBYBYH2007 içerisinde tanımlanan elastik spektruma uygun olarak genlik ölçeklemesi yöntemi ile ölçeklendirilen yönelim etkisi ortadan kaldırılmıș deprem kayıtları kullanılmıștır. Ölçeklendirmelerde, incelenen her bir yapının ötelenme titreșim modları dikkate alındığından 
DEÜ FMD 23(68), 489-500, 2021

ölçekleme katsayıları farklılıklar ve uzaklık değerlerine bağlı olarak seçilmiștir göstermektedir. Kulanılan deprem kayıtları [21]. Kayıtlara ait karakteristik bilgiler Tablo 1, Pacific Earthquake Engineering Research Center ivme-zaman serileri Şekil 3 ve ölçeklenen (PEER) veri tabanından, yönetmelikte spektral değerlerin hedef spektrum ile beraber belirtildiği üzere, fay mekanizması, zemin sınıfı gösterimi Şekil 4 içerisinde verilmiştir.

Tablo 1. Deprem kayıtlarına ait veriler

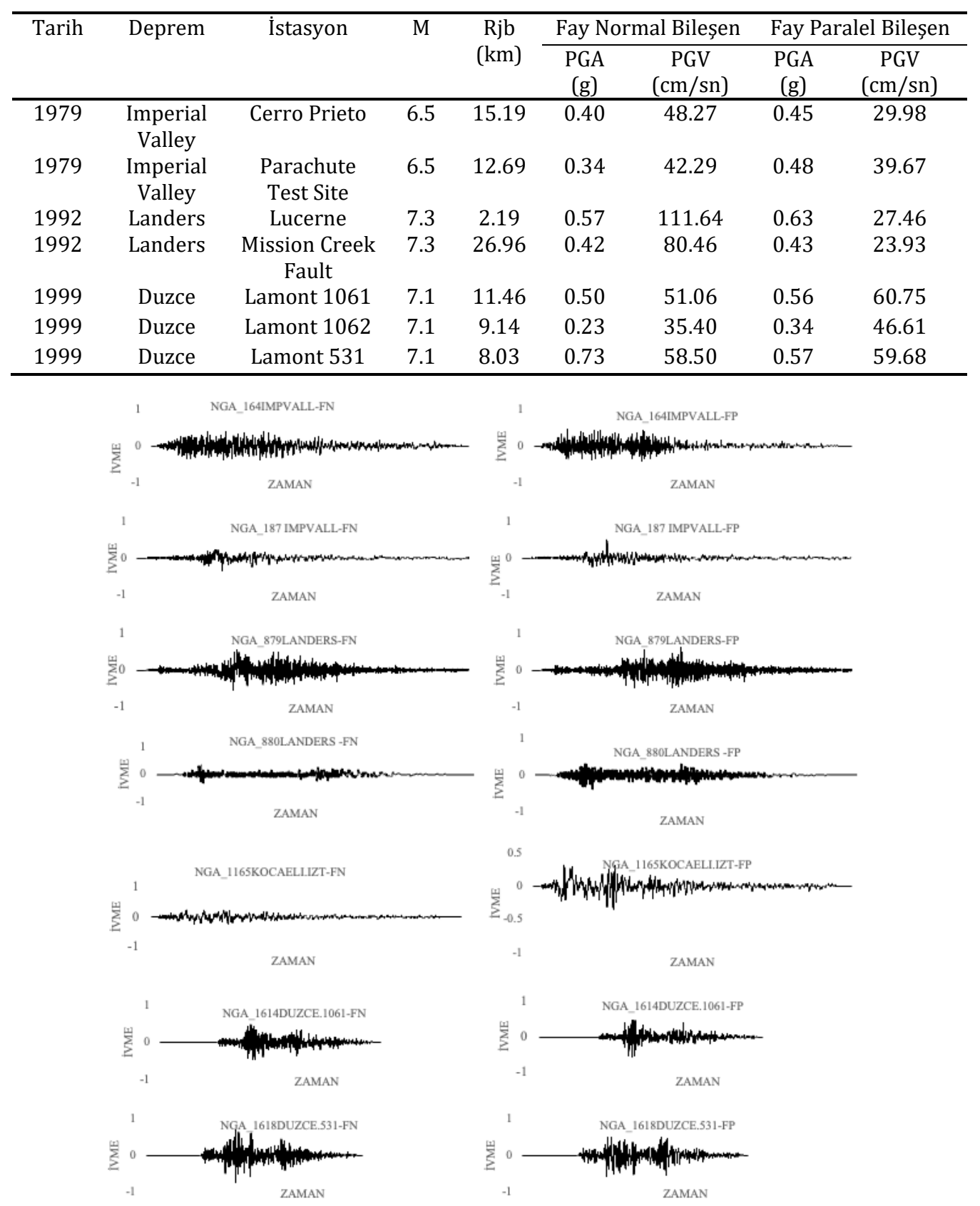

Şekil 3. Deprem yer hareketlerinin zaman serileri 

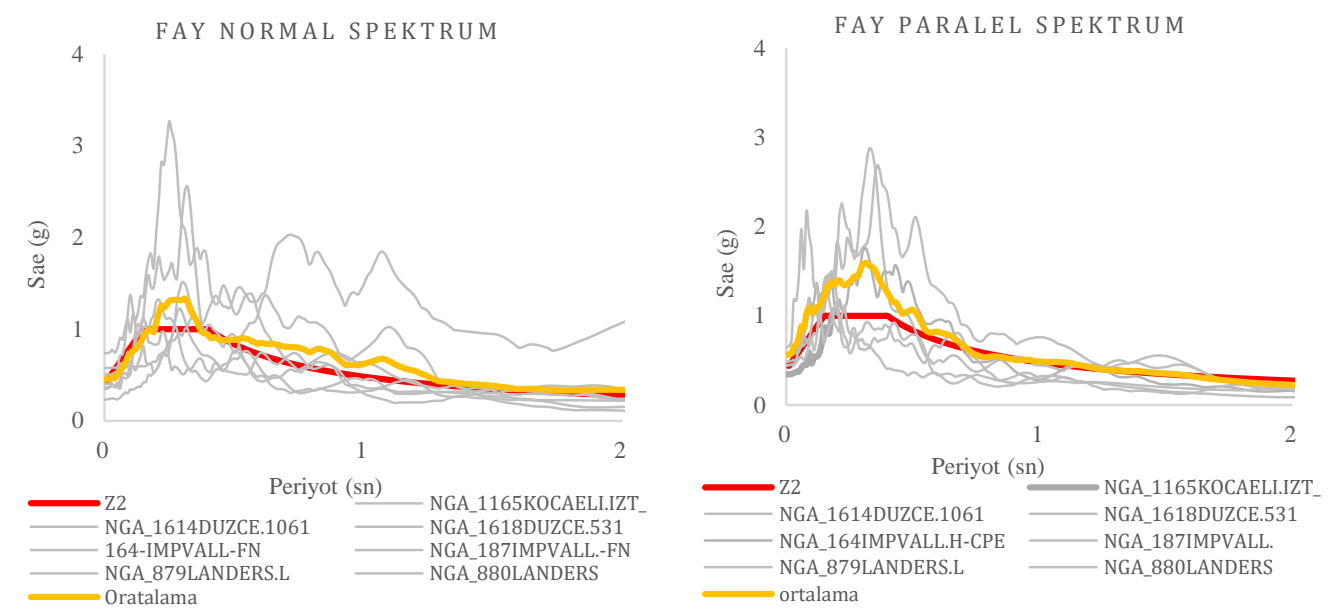

Şekil 4. Deprem kayıtlarının fay normal ve paralel doğrultularının elastik spektrumları

\subsection{Zaman tanım alanındaki analizleri}

Sinıflandırılması yukarıda belirtilen dört gruptaki yapiların hepsinde, deprem yatay dik bileşenleri $15^{\circ}$ lik açllarla döndürülerek zaman tanım alanında doğrusal hesaplamalar (ZTADH) yapılmıștır. Aynı zamanda, her bir yapıda, depremin etki yönünden bağımsız olarak Eşdeğer Deprem Yüklemesi (EDY) ile analizler yapılmıştır. Yönetmeliklerde belirtilen ortak etki formülleri dikkate alınarak, en elverișsiz yanal yükleme durumu belirlenmiștir. Her iki hesap yönteminin uygulandığı analizlerin sonuçlarının

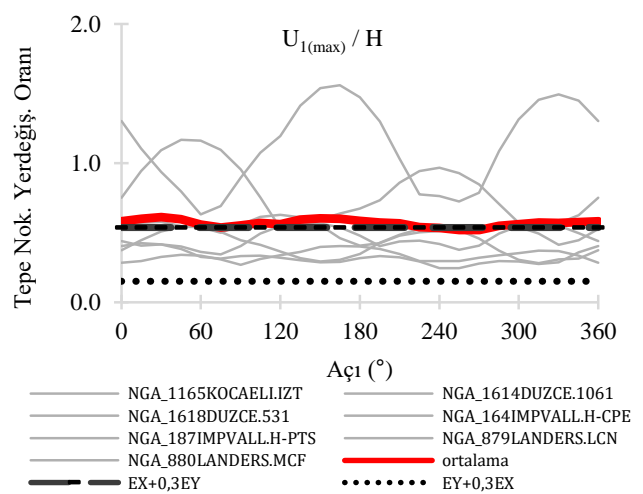

karşılaştırılması için belirlenen bir eksendeki yapı tepe yer değiștirmesi ve aynı eksendeki taban kesme kuvveti değerleri, sırasıyla, yapı yüksekliği ve bina ağırlığına bölünerek normalize edilmiștir. $\mathrm{Bu}$ sayede, tamamlanan analizlerin aynı şekil üzerinden gösterimi ve dolayısıyla da sayısal karşılaştırılması mümkün olmuştur. ZTADH yönteminde deprem kuvvet çiftlerini yapıya farklı doğrultularda etki elde edilen analiz sonuçları ile doğrultu etkisi kavramı incelenmiş ve bu sonuçlar diğer analiz yöntemi (EDY) sonuçları ile de karşılaştırılmıştır (Şekil 5-8).

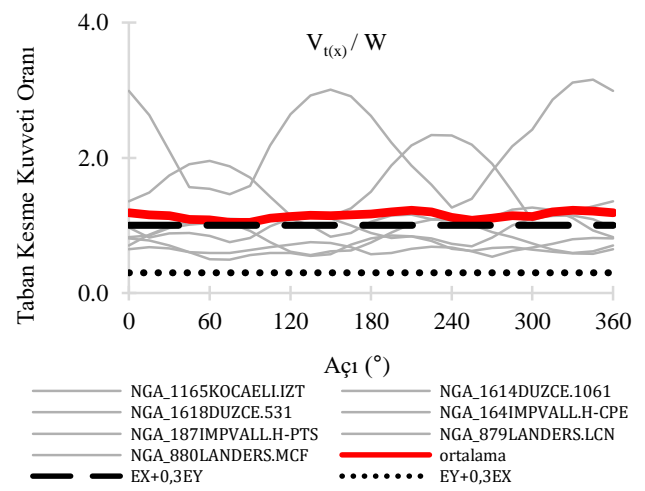

Şekil 5. Düzenli-Burulmasız yapı sınıfı için X doğrultusu tepe noktası yer değiştirmesi ve taban kesme kuvveti oranları 

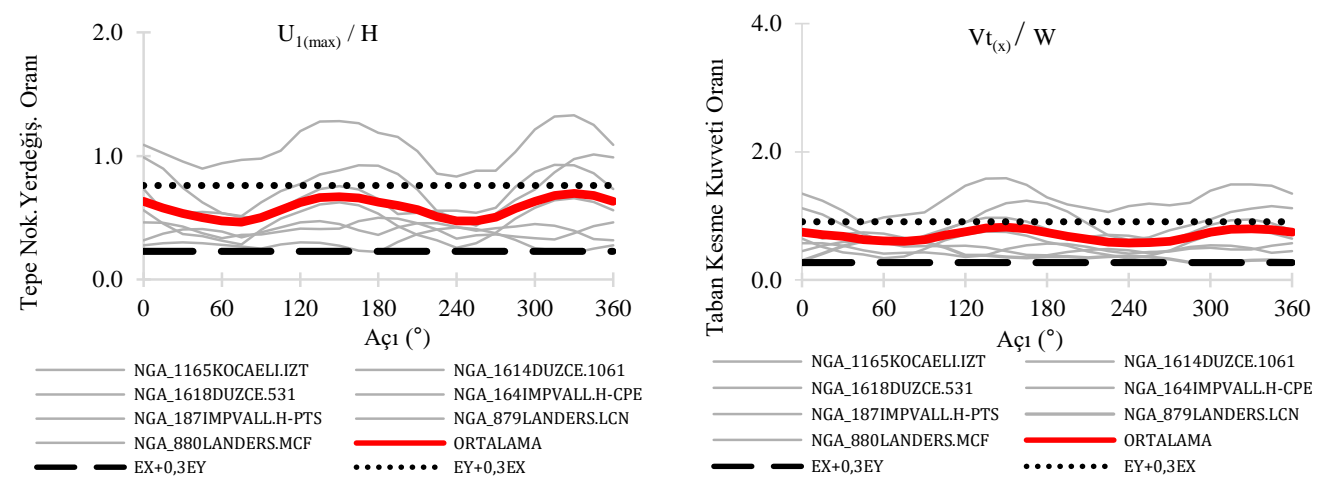

Şekil 6. Düzensiz-Burulmasız yapı sınıfı için X doğrultusu tepe noktası yerdeğiştirmesi ve taban kesme kuvveti oranları
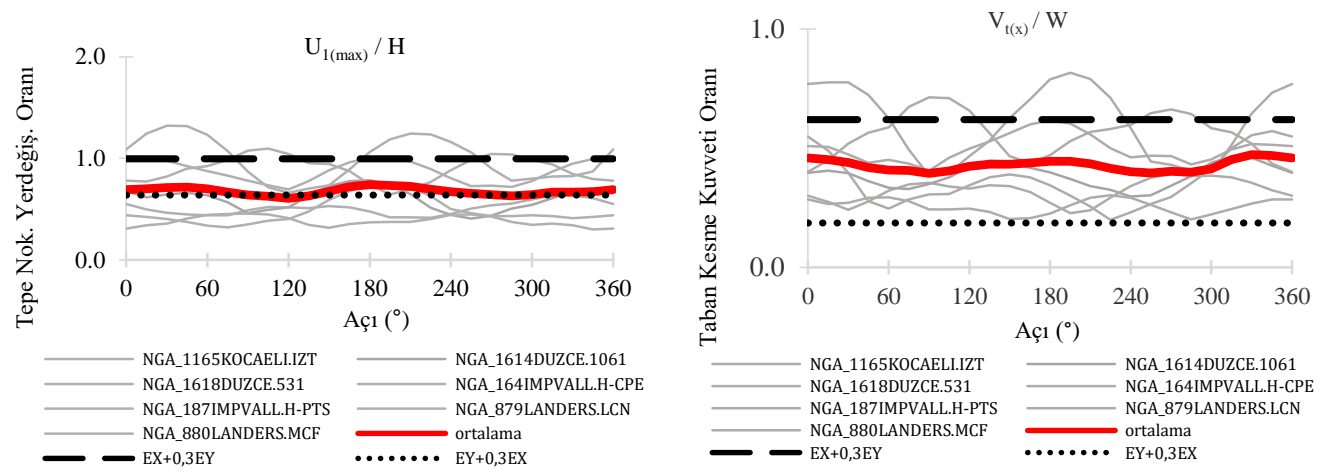

Şekil 7. Düzenli-Burulmalı yapı sınıfı için X doğrultusu tepe noktası yerdeğiştirmesi ve taban kesme kuvveti oranları
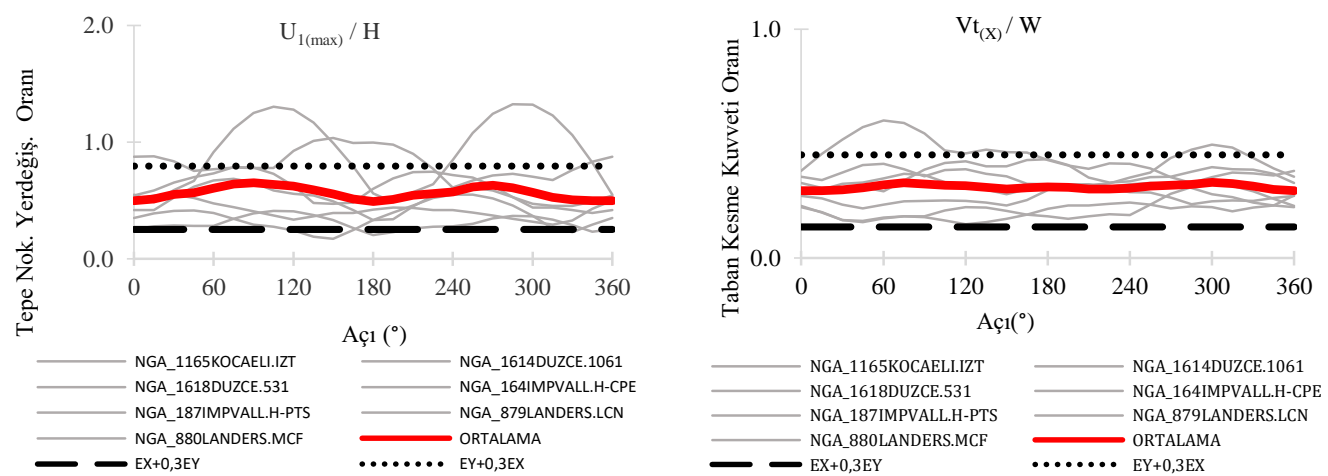

Şekil 8. Düzensiz-Burulmalı yapı sınıfı için X doğrultusu tepe noktası yerdeğiştirmesi ve taban kesme kuvveti oranları

Elde edilen grafik sonuçlarından görüldüğü gibi ZTADH yöntemi kullanılarak hesaplanan ortalama değerler, yönetmelik kurallarınca tavsiye edilen formüller ile hesaplanan değerlere oldukça yakın değerler vermiştir. Bu durumda bu yapı için ortak etki formüllerinin yeterli olduğunu söylemek yanlış olamayacaktır. Örnek yapılar için $45^{\circ}, 135^{\circ}, 210^{\circ}$ ve $330^{\circ}$ ile etkiyen deprem kuvvetleri etkisi altında daha yüksek tepki oranı değerleri vermektedir. 
DEÜ FMD 23(68), 489-500, 2021

\subsection{Kritik Açı Doğrultusunun Belirlenmesi}

Kapsamlı analizler sonucu elde edilen mühendislik talep parametreleri (tepe yerdeğiștirmeleri, taban kesme kuvvetleri) istatistiksel olarak değerlendirilmiştir [22]. Sonuçların anlamlandırılmasında her bir yapı sınıfı için döndürülen açlarda elde edilen büyüklükler histogram olarak görselleștirilmiştir. Yapının sınıflarının, ilgili parametreler ile filtrelenmesi durumunda ortaya çıkan kritik etki doğrultuları araştırılmış olup elde edilen genel histogramlar Şekil 9 içerisinde verilmiştir.
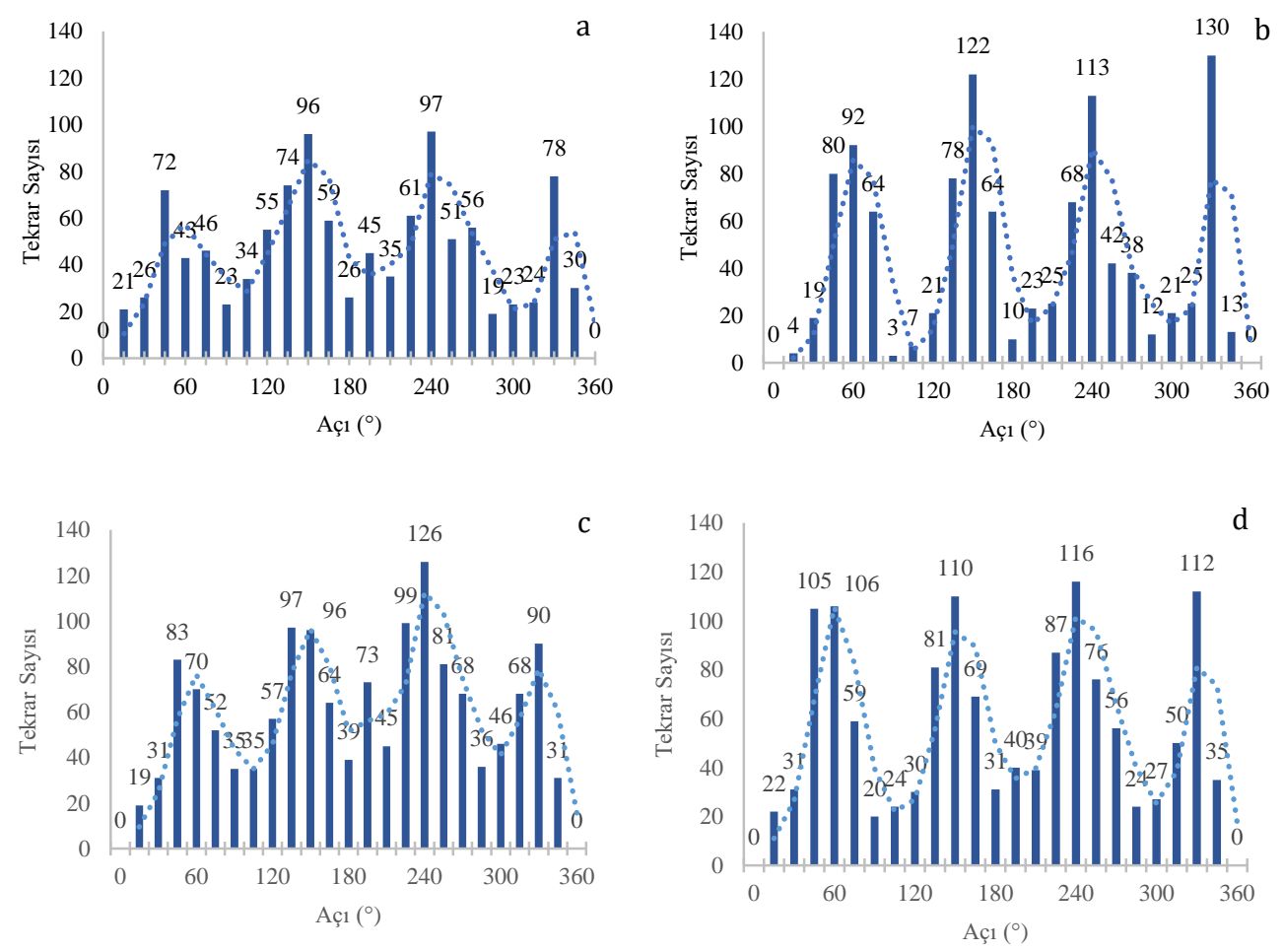

Şekil 9. Genel histogramlar; a) Planda düzenli-burulmasız, b) Planda düzensiz-burulmasız c) Planda düzenli-burulmalı, d) Planda düzensiz-burulmalı

Histogramlar her yapı sınıfı için kullanılan deprem kayıtları aynı olmasına rağmen yapı geometrisine bağlı olarak en büyük tepki kuvvetlerinin meydana geldiği açllar değișmiș ve belirli bir eğilimi işaret etmiştir. Planda düzenli burulmasız yapı sınıfına ait genel histogram sonuçları incelendiğinde kritik açı değerlerinin yaklaşık $45^{\circ}, 135^{\circ}, 240^{\circ}$ ve $330^{\circ}$, planda düzensiz burulmasız yapı sınıfina ait histogramda görüldüğü gibi bu yapı tipleri için $60^{\circ}$ ile başlayan bir eğilim, 150 derecede oldukça yükselmiş, $240^{\circ}$ ve $330^{\circ}$ ile devam etmiștir. Planda düzenli burulmalı yapı sınıfina ait histogramlarda bu açı değerlerinin $45^{\circ}, 135^{\circ}$, $240^{\circ}$ ve $330^{\circ}$ olduğu, planda düzensiz perdeli yapı sınıfı için ise $45^{\circ}, 60^{\circ}$ ile başlayan bir eğilim, $150^{\circ}$ ile takip etmiş, $240^{\circ}$ ve $330^{\circ}$ ile devam etmiştir.

\section{Sayısal örnek}

İncelenen yapı grubuna ek olarak bir adet vaka çalışması yapılmış ve örnek bir yapı için kritik etki doğrultusu kavramı incelenmiştir. Vaka çalışmasında incelenen örnek, planda düzensizburulmalı yapı sınıfına örnek olmuştur. Bu yapının kritik etki doğrultusu kavramını araştırmak için planda düzensiz-burulmalı yapı sınıfına ait histogram sonuçlarından yararlanılmıștır. İncelenen yapı, Şekil 10, DBYBYH-2007'ye göre birinci derece deprem bölgesi olan İstanbul-Pendik ilçesinde bulunmaktadır. 
DEÜ FMD 23(68), 489-500, 2021

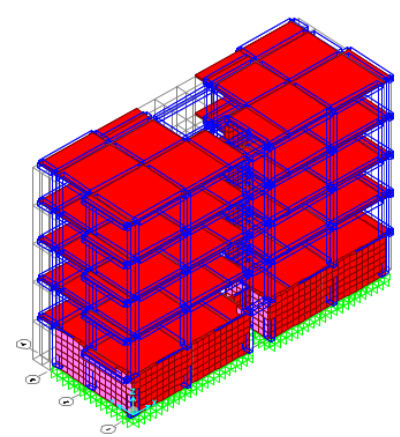

Şekil 10. Eşit Apartmanı'nın görünümü

Yapıda, beton sınıfı C25/30, çelik sınıfı ise S420 olarak kullanılmıştır. Yapının matematik modellenmesi CSI SAP2000 v.16'da gerçekleşmiştir. Yapıdaki elemanların boyutları; kolonlar için $30 \mathrm{~cm} \times 30 \mathrm{~cm}$ ve $30 \mathrm{~cm} \times 60 \mathrm{~cm}$ ölçüleri, kirişler için $25 \mathrm{~cm} \times 50 \mathrm{~cm}, 30 \mathrm{~cm} \times 30 \mathrm{~cm}$ ve $50 \mathrm{~cm} \times 30 \mathrm{~cm}$ ölçüleri, perde duvar kalınlığı $25 \mathrm{~cm}$ ve döșeme kalınlığı ise $13 \mathrm{~cm}$ olarak tasarlanmıștır.

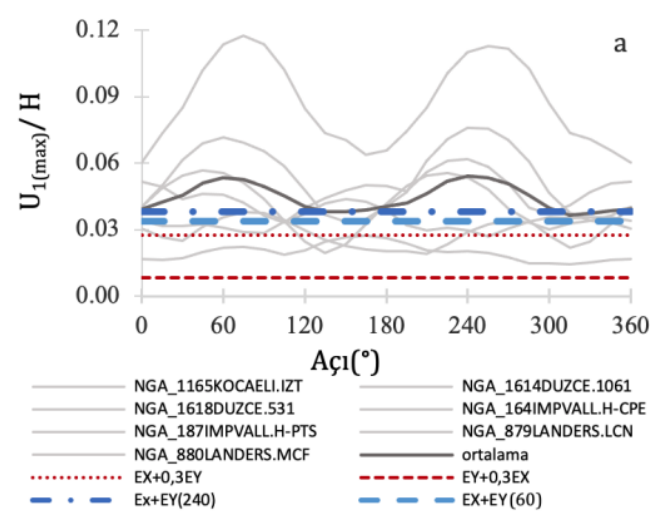

Eşit Apartmanı için kritik etki açısı doğrultusu değerlendirmesi yapılırken ilgili sınıfa ait histogramlardan elde edilen açı değerleri $60^{\circ}$ ve $240^{\circ}$ olarak belirlenmiştir. Eşit Apartmanı'nın kritik etki doğrultusu kavramı araştırması kapsamında deprem kuvvet çiftleri yapıya belirlenen kritik etki açısı doğrultularında etki ettirilmiştir. Grafiklerde önerilen $60^{\circ}$ ve $240^{\circ}$ açılarda yapılan hesaplamalarda, sırasıyla, açık mavi uzun kesikli çizgi ve koyu mavi noktalı kesikli çizgiler ile gösterilmiştir. Zaman tanım alanındaki analizlerin sonuçları ve ortalaması düz çizgiler ile ifade edilmiștir. "Ortak Etki Formülleri" olarak ifade edilen Ex+0.3Ey ve Ey+0.3Ex analiz sonuçları, sırasıyla, kırmızı noktalar ve kırmızı kısa kesikli çizgiler ile gösterilmiştir. Sonuç grafiklerinden $\mathrm{X}$ doğrultusu (uzun kenar) tepe yerdeğiştirmesi ve taban kesme kuvveti oranı grafikleri Șekil 11 içerisinde, Y doğrultusuna (kısa kenar) ait grafikler ise Şekil 12 içerisinde paylaşılmıştır.

Şekil 11. Eşit Apartmanı için kritik etki açısı doğrultusu değerlendirmesi: $X$ doğrultusu (a) tepe noktası yerdeğiștirmesi ve (b) taban kesme kuvvetleri oranı
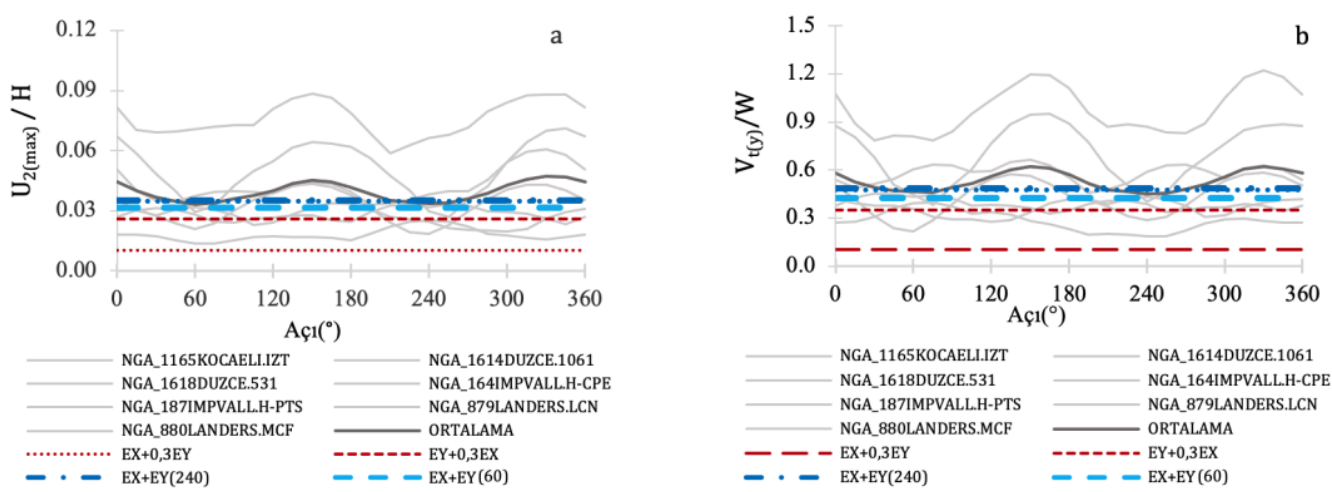

Şekil 12. Eşit Apartmanı için kritik etki açısı doğrultusu değerlendirmesi: Y doğrultusu (a) tepe noktası yerdeğiștirmesi ve (b) taban kesme kuvvetleri oranı 
Yapının tepe yerdeğiștirmesi oranı, taban kesme kuvvetleri oranı grafikleri sonucu kritik etki doğrultusu kavramının önemi ortaya çıkmıştır. Söz konusu yapı genelinde, deprem kuvvetlerinin yapıya önceden belirlenen kritik etki doğrultusu açı değerlerinde etkimesi durumunda daha büyük tepki kuvvetleri oluşmaktadır. Özellikle $240^{\circ}$ ve $330^{\circ}$ ile yapıya etkiyecek deprem kuvvetleri etkisi altında yapıda diğer açılar ile etkiyen deprem kuvvetlerinden, yönetmelikte verilen ortak etki formülleri ile yapılan analiz sonuçlarından ve ZTADH yöntemi kullanılarak elde edilen analiz sonuçlarından oldukça büyük tepki değerleri ortaya çıkmıștır.

\section{Sonuçlar}

Bu çalıșmada, mevcut yönetmelikler içerisinde yatay etkilerini bir arada değerlendirilmesi için verilmiș olan "Ortak Etki Formüllerinin" ağırlıklı katsayıların geçerliliği ve yatay etkilerin yapı asal eksenleri dıșında olması halinde mühendislik istem değerlerinin değișimi istatiksel olarak değerlendirilmiștir. Seçilen bir deprem büyüklügü seviyesi için oluşturulan elastik tepki spektrumuna uyumlu yedi çift deprem kaydı elde edilmiștir. Ülkemizdeki mevcut yapı stoğu içerisinde tipik olarak bulunan binalardan; planda düzenli ve düzensizlik ile düșey eksen etrafında burulma oranının, yönetmelik limitlerinden az veya fazla olması durumuna göre dört sınıf yapı örneği belirlenmiştir. Her bir sınıfa ait kat (1-5 adet kat) ve açıklık (2-5 aks) değişimine göre yapılan matematiksel olarak modellenmiștir. Toplam 185 farklı binanın elemanlarının kesit tasarımında yönetmeliklerde belirtilen elastik tasarım limitlerine dikkat edilmiștir. Her bir bina modeli için, seçilen deprem kayıt çiftleri asal eksenden $15^{\circ}$ adımlarla döndürülerek zaman tanım alanında doğrusal hesaplamalar yapılmıștır. Toplamda 32,375 adet zaman serisi analizi geliștirilen bir bilgisayar programı aracığıyla kısa sürede tamamlanmıştır. Elde edilen analiz sonuçları istatiksel olarak değerlendirilmiştir. İstatiksel çalışma sonucunda her bir yapı sınıfı için, asal eksenlere göre daha fazla deprem istemi yaratan kritik açılar belirlenmiştir. Önerilen kritik açı yaklaşımı, profesyonel mühendislik hizmeti alarak imal edilmiş bir bina üzerinde geçerliliği sınanmıştır.
Gerçekleştirilen kapsamlı analizlerin istatiksel sonuçlarına bağlı olarak aşağıdaki sonuçlara ulaşılmıştır;

- Yapı modellerinin zaman tanım alanı ve "ortak etki formülleri" ile yapılan analizleri sonucunda, önerilen açlarda hesaplanan mühendislik talep parametrelerinin, yönetmeliklerde verilen asal eksendeki hesaplamalara göre daha büyük çıktığı görülmüștür.

- Planda düzenli-burulmasız ile Planda düzenli-burulmalı yapılarda $45^{\circ}$ ve $135^{\circ}$ lerde, Planda düzensiz-burulmasız ve Planda düzensiz-burulmalı yapılarda ise 60$150^{\circ}$ lerde deprem etkisinin arttığı belirlenmiştir. Benzer şekilde, bu yönlerin zıttı olan açılarda da benzer sonuçlara varılmıştır.

- Belirlenen açlarında, incelenen örnek kümesi dışında yer alan mühendislik tasarımı görmüş bir bina üzerinde yapılan incelemede, önerilen yaklaşımın gerçekten de sayısal olarak daha büyük iç kuvvet ve yerdeğiștirmelerin olduğu gözlemlenmiștir.

Daha güvenli yapılar için, kuvvet esaslı tasarım yaklaşımlarında yapı geometrisine bağlı olarak kritik açı etkisinin ele alınması gereken bir büyüklük olduğu bu çalışma ile gösterilmiştir.

\section{Kaynakça}

[1] Özmen G., Pala S., Gülay G., Orakdöğen E. 1998. Çok Katlı Yapılarda Yapısal Düzensizliklerin Deprem Hesabına Etkisi, Teknik Rapor No: TDV/TR 017, 78s., İstanbul.

[2] Rosenblueth E., Contreras, H., 1997. Approximate design for multicomponent earthquakes, Journal of Engineering Mechanics (ASCE), Cilt. 103(5), s. 881893. DOI: -

[3] Newmark N.M. 1975, Seismic design criteria for structures and facilities,trans-alaska pipeline system, U.S. National Conference on Earthquake Engineering, 18-20 Haziran, Michigan, 94-103.

[4] Wilson, Suharwardy, I., Habibullah, A., 1995. A clarification of the orthogonal effects in a threedimensional seismic analysis, Earthquake Spectra, Cilt: 11(4), s. 659-666. DOI: 10.1193/1.1585831

[5] Menun C., Kiureghian A.D. 1998. A replacement for the $30 \%, 40 \%$, and SRSS rules for multicomponent seismic analysis, Earthquake Spectra, Cilt: 14(153), s. 153-163. DOI: $10.1193 / 1.1585993$

[6] Lopez, O.A. ,Torres R. 1997. The critical angle of seismic incidence and the maximum structural response, Earthquake Engineering and Structural Dynamics, Cilt. 26(9), s. 881-894. DOI: 10.1002/(SICI)1096-

9845(199709)26:9\%3C881::AID-

EQE674\%3E3.0.CO;2-R 
DEÜ FMD 23(68), 489-500, 2021

[7] Ozmen G. 2005. Ortogonal olmayan yapilarda maksimum donatı oranlarının tayini, TMMOB İnşaat Mühendisleri Odası Teknik Dergi, Cilt. 16(1), s. 3445.

[8] Sebastiani P., Liberatore L., Lucchini A.,Mollaioli F. 2018. A new method to predict the ciritical incidence angle for buildings under near-fault motions, Structural engineering and mechanics, Cilt: 68(5), s. 575-589 DOI: 10.12989/sem.2018.68.5.575

[9] Magliulo G, Maddaloni G, Petrone C. 2014. Influence of earthquake direction on the seismic response of irregular plan RC frame buildings. Earthquake Engineering and Engineering Vibration, Cilt. 13(2), s. 243-256. DOI: $10.1007 / \mathrm{s} 11803-014-0227-z$

[10] Kostinakis K, Morfidis K, Xenidis H. 2015. Damage response of multistory $\mathrm{r} / \mathrm{c}$ buildings with different structural systems subjected to seismic motion of arbitrary orientation. Earthquake Engineering and Structural Dynamics, Cilt. 44(12), s. 1919-1937. DOI: $10.1002 /$ eqe. 2561

[11] Giannopououls D., Vamvatsikos D. 2018. Ground motion records for seismic performance assessment:To rotate or not to rotate?, Earthquake Engineering and Structural Dynamics, Cilt: no. 12, c. 2410-2425, DOI:10.1002/eqe.3090

[12] Altunıșık A., Kalkan E., Earthquake incidence angle influence on seismic performance of reinforced concrete buildings., 2017, Sigma Journal of Engineering and Natural Sciences, Cilt. 35(4), s. 609 631. DOI: -

[13] Kalkan E, Kwong NS. 2014. Pros and cons of rotating ground motion records to fault normal/parallel directions for response history analysis of buildings. Journal of Structural Engineering, Cilt. 140(3), s. $04013062 . \quad$ DOI $: 10.1061 /$ (ASCE)ST.1943541X.0000845

[14] Reyes JC, Kalkan E. 2015. Significance of rotating ground motions on behavior of symmetric- and asymmetric-plan structures, part I: single-story structures. Earthquake Spectra, Cilt. 31(3), s. 15911612. DOI: $10.1193 / 072012 \mathrm{EQS} 241 \mathrm{M}$

[15] Reyes JC, Kalkan E. 2015. Significance of rotating ground motions on behavior of symmetric- and asymmetric-plan structures, part II: multi-story structures. Earthquake Spectra, Cilt. 31(3), s. 16131628. DOI: $10.1193 / 072012 \mathrm{EQS} 242 \mathrm{M}$

[16] Hasgül U. 2011, Betonarme Binaların Sekil Değiştirme Esaslı Doğrusal Olmayan Analizinde Deprem Doğrultusu Etkisinin İncelenmesi, Balıkesir Üniversitesi, Fen Bilimleri Enstitüsü, Doktora Tezi, 223s, Balıkesir.

[17] Resmi Gazete, 2007, Deprem Bölgelerinde Yapılacak Binalar Hakkında Yönetmelik, 6 Mart 2007 tarih ve 26454 sayılı Resmi Gazete.

[18] Di Sarno, L., Amiri, S., Garakaninezhad, A. 2020. Effects of incident angles of earthquake sequences on seismic demands of structures. Structures, Cilt. 28, s.1244-1251. DOI: 10.1016/j.istruc.2020.09.064

[19] Computers \& Structures. SAP2000 2016.

[20] Türkhan A, Tuğan B, Dindar AA, Önen YH. 2014. A Cloud Computer Applicaton In Civil Engineering Education And Research: SAMA. 11 th Int. Congr. Adv. Civ. Eng., 21-25 Ekim, İstanbul .

[21] PEER Kuvvetli Yer Hareketi Veri Tabanı, https://ngawest2.berkeley.edu/, (Erişim tarihi: 12.08.2019).
[22] Ayar B. 2019, Yapıların Burulma Düzensizliği ve Depremin Doğrultuları Arasındaki İlișki, Gebze Teknik Üniversitesi, Fen Bilimleri Enstitüsü, Yüksek Lisans Tezi, 126s., Kocaeli. 